\title{
Adsorption Studies of Trifluralin on Chitosan and its Voltammetric Determination on a Modified Chitosan Glassy Carbon Electrode
}

\author{
Acácia Maria dos Santos Melo, Iara Barros Valentim, Marilia O. F. Goulart* and \\ Fabiane Caxico de Abreu*
}

\author{
Instituto de Química e Biotecnologia, Universidade Federal de Alagoas, 57072-970 Maceió- AL, Brazil
}

\begin{abstract}
Os estudos sobre adsorção do herbicida trifluralina (TRF) em quitosana foram realizados em batelada, usando temperaturas entre 298 e 313 K. Os resultados de adsorção ajustaram-se perfeitamente ao modelo de adsorção de Langmuir. O valor de entalpia obtido $-10,2 \pm 0,8 \mathrm{~kJ}$ $\mathrm{mol}^{-1}$ confirma que a interação TRF-quitosana é exotérmica e que o processo de adsorção é relativo à interação eletrostática entre o grupo amônio da quitosana e o dipolo negativo dos grupos substituintes de TRF, sendo dependente da força iônica. Estudos voltamétricos mostraram que TRF apresentou dois picos de redução em eletrodo de $\mathrm{CV}$, ambos de natureza difusional e irreversível, referentes à redução dos grupos nitroaromáticos. A corrente do primeiro pico de redução intensificou-se no eletrodo de carbono vítreo modificado com quitosana, em comparação com o eletrodo não modificado. Isto foi atribuído à adsorção/acumulação de TRF em quitosana. A corrente de redução em voltametria de pulso diferencial foi proporcional à concentração de TRF na faixa de $2,49 \times 10^{-7}$ a $5,79 \times 10^{-6} \mathrm{~mol} \mathrm{~L}^{-1}$, com limite de detecção de $7,45 \times 10^{-8} \mathrm{~mol} \mathrm{~L}^{-1}$.
\end{abstract}

The studies about adsorption of the herbicide trifluralin (TRF), on chitosan, were carried out by batch methods using temperatures from 298 up to $313 \mathrm{~K}$. The adsorption results were well fitted to Langmuir adsorption model. The obtained enthalpic value of $-10.2 \pm 0.8 \mathrm{~kJ} \mathrm{~mol}^{-1}$ confirms that the TRF-chitosan interaction is exothermic and that the adsorption process is relative to electrostatic interaction between the ammonium group of chitosan and the negative dipole of the substituent groups of TRF, being dependent on ionic strength. Voltammetric studies showed that TRF exhibited two irreversible, diffusional reduction waves related to the reduction of the nitroaromatic groups. The current of the first reduction peak intensified on the chitosan-modified glassy carbon electrode in comparison with the unmodified one. This was attributed to the adsorption/accumulation of TRF on chitosan. The reduction current, using Differential Pulse Voltammetry, was proportional to the concentration of TRF in the range of $2.49 \times 10^{-7}$ to $5.79 \times 10^{-6} \mathrm{~mol} \mathrm{~L}^{-1}$, with a detection limit of $7.45 \times 10^{-8} \mathrm{~mol} \mathrm{~L}^{-1}$.

Keywords: adsorption, trifluralin, electroanalytical, chitosan

\section{Introduction}

Water pollution by pesticides from routine agricultural practices is a common and growing problem in the major agricultural areas of the world. Herbicide contamination of water systems has been of major concern in recent years. Trifluralin [2,6-dinitro- $N, N$-dipropyl-4-(trifluoromethyl) aniline, CAS 1582-09-8] is a dinitroaniline pre-emergence herbicide used for the control of broadleaf weeds in a wide variety of crops including cotton, brassica, soybeans and ornamentals, among others. ${ }^{1}$ TRF is a relatively immobile herbicide in soils so there is little hazard for groundwater

\footnotetext{
*e-mail: mofg@qui.ufal.br; fca@qui.ufal.br
}

contamination, however it has a tendency to volatilize, ${ }^{2}$ with vapor pressure $1.5 \times 10^{-2} \mathrm{~Pa}^{3}$ and Henry Constant $\mathrm{H}=16.8 \mathrm{~Pa} \mathrm{~m}^{3} \mathrm{~mol}^{-1}$ at $25^{\circ} \mathrm{C}$, hence it can relatively easily enter the atmosphere. ${ }^{3}$ It has been detected in the air at concentrations of the order of $\mathrm{ng} \mathrm{m}^{-3}$. Its degradation in soil involves a series of oxidative dealkylation steps, the reduction of the nitro group, and oxidative cyclization, resulting in the formation of small quantities of several transformation products as well as significant amounts of non-extractable soil-bound compounds that reside in the fulvic and humic acid fractions of soils. ${ }^{5-7}$ Its half-life is 3-18 weeks, depending on soil type and geographical location. ${ }^{2}$

Although many treatment processes have been proposed for the removal of environmental contaminants 
from an aqueous solution, adsorption is considered to be of particular importance for purification and separation process in an industrial scale. Chitosan, a product derived from chitin by alkaline $\mathrm{N}$-deacetylation, is a natural, nontoxic, biodegradable, and hydrophilic polymer. ${ }^{8}$ Several studies have been performed to investigate the adsorption performance of chitosan for the removal of polluents from aqueous solutions due to its low cost and potential metal binding capacities. ${ }^{9-18}$

The main objective of this work is, thus, to investigate the possible interaction between chitosan and TRF in solution through spectrophotometry in order to get the mechanism of the possible interaction, with the aim of using chitosan in decontamination. In order to quantify trifluralin in solution, electrochemical methods were chosen and a modified electrode based on chitosan was prepared, used, and compared to other methods of analysis.

The maximum allowed quantity of TRF in water is $0.2 \mu \mathrm{g} \mathrm{L}{ }^{-1} .{ }^{19}$ Several methods, ${ }^{20-29}$ including electroanalytical ones, ${ }^{28,29}$ are used to determine this class of pesticides in solution or in real samples. Trifluralin and compounds of the same series (dinitroanilines) were earlier quantified in food, using biosensors. ${ }^{25-27}$

\section{Experimental}

Trifluralin (TRF) (99\% purity) was purchased from Sigma-Aldrich (St. Louis-MO, USA) and used as received. Highly purified $18.2 \mathrm{M} \Omega$ water was used in the preparations of all solutions. Chitosan was purchased from SigmaAldrich, (St. Louis-MO, USA) and used as received.

\section{Adsorption experiments}

Adsorption experiments were carried out using batch method. $0.180 \mathrm{~g}$ of chitosan were weighed and suspended in sealed Erlenmeyer flasks containing suitable amounts of acidified water ( $\mathrm{pH}=4.0$, using conc. $\mathrm{HCl}$ ), for $15 \mathrm{~min}$, necessary for attaining $\mathrm{pH}$ 7.0. After this time, suitable amounts of an ethanolic stock solution of TRF were added up to a total volume of $30 \mathrm{~mL}$, to get various concentrations ranging from 0.010 to $0.217 \mathrm{~g} \mathrm{~L}^{-1}$. Suspensions were shaken in a thermostated incubator (Marconi, Brazil) for $1.5 \mathrm{~h}$ at constant temperature $(298,303,308$ and $313 \mathrm{~K})$. After pre-determined time periods, chitosan was removed from the suspensions by filtration. The residual concentration of the TRF in the filtrate was measured by Shimadzu Multispec-1501 UV-VIS spectrophotometer (Wilmington, USA), at $274 \mathrm{~nm}$. The amount of TRF adsorbed on the chitosan was calculated from the difference between initial and final TRF concentrations.

\section{Rate of adsorption}

The kinetic curve was obtained at $298 \mathrm{~K}$ with $0.180 \mathrm{~g}$ of chitosan and $0.010 \mathrm{~g} \mathrm{~L}^{-1}$ of TRF. The amount of TRF adsorbed was measured as a function of incubation time. All experiments were performed in triplicate.

\section{Ionic strength dependence}

Isotherms at $298 \mathrm{~K}$ were obtained with and without ionic strength control ( 0 and $0.01 \mathrm{~mol} \mathrm{~L}^{-1}$ of $\left.\mathrm{NaCl}\right)$, as described above, with $0.180 \mathrm{~g}$ of chitosan and varying the TRF concentrations from 0.010 to $0.217 \mathrm{~g} \mathrm{~L}^{-1}$. The incubation time used was $1.5 \mathrm{~h}$. All experiments were performed in triplicate.

\section{Electrochemical experiments}

Cleaning of GCE surface: glassy carbon electrodes (GCE, BAS, diameter of $3 \mathrm{~mm}$ ) were polished with 0.1 um alumina, followed by sonication in water for 2 min.

\section{Preparation of chitosan-modified electrode GCE/CHI}

A chitosan solution was prepared by dissolving $1.0 \mathrm{mg}$ of chitosan flakes into $2 \mathrm{~mL}$ of $0.1 \mathrm{~mol} \mathrm{~L}^{-1}$ acetic acid and stirred for $2 \mathrm{~h}$ at room temperature until complete dissolution. The chitosan solution was stored in refrigerator when not in use. For the fabrication of GC/CHI electrode, $5,10,15,20$ or $25 \mu \mathrm{L}$ of chitosan solution was pipetted onto the GCE surface and naturally dried, and then it was rinsed with water to remove residual acetic acid.

Electrochemical measurements were made using glassy carbon electrode (GCE) or chitosan-modified glassy carbon (GCE/CHI) as the working electrode, an $\mathrm{Ag} / \mathrm{AgCl}$, $\mathrm{Cl}^{-}$reference electrode and a platinum wire as auxiliary electrode. The electrochemical properties were studied by means of cyclic voltammetry (CV), differential pulse voltammetry (DPV), potential-controlled coulometry (PCC) with an Autolab potentiostat-galvanostat (PGSTAT 20). The experiments were carried out in $0.20 \mathrm{~mol} \mathrm{~L}^{-1}$ of phosphate buffer + ethanol (1:1) solution (apparent $\mathrm{pH}$ 6.9) purged with nitrogen for at least $10 \mathrm{~min}$ prior to a series of experiments.

After the modified electrode was stored at $4{ }^{\circ} \mathrm{C}$ for one week, the currents for the direct electron transfer of TRF were reproducible. The good stability of the modified electrode may be ascribed to efficient adhesion, high mechanical strength of the chitosan polymer and stability. 
For reduction and oxidation experiments, $\mathrm{CV}$ and DPV of solutions of TRF $\left(c_{\mathrm{TRF}} 1 \times 10^{-3} \mathrm{~mol} \mathrm{~L}^{-1}\right.$ or $\left.1 \times 10^{-4} \mathrm{~mol} \mathrm{~L}^{-1}\right)$ in aqueous phosphate buffer + ethanol (1:1) $\left(0.2 \mathrm{~mol} \mathrm{~L}^{-1} ; \mathrm{pH}\right.$ 6.9) were performed using a bare GCE or the GC/CHI electrode. For DPV measurements, the pulse amplitude was $50 \mathrm{mV}$, the pulse width was $70 \mathrm{~ms}$ and the scan rate was $0.020 \mathrm{~V} \mathrm{~s}^{-1}$. In CV experiments, the scan rate was varied from 0.020 to $2 \mathrm{~V} \mathrm{~s}^{-1}$ : a scan rate of $0.100 \mathrm{~V} \mathrm{~s}^{-1}$ was chosen in order to measure the reported parameters. Exhaustive coulometry was performed using a divided cell with a carbon felt $(26 \times 13 \times 5 \mathrm{~mm})$, platinum and $\mathrm{Ag} / \mathrm{AgCl}$ as the working, auxiliary and reference electrodes, respectively. The electrolysis of TRF ( $80 \mathrm{mg} ; 0.24 \mathrm{mmol})$, in aqueous phosphate buffer + ethanol (1:1), $0.2 \mathrm{~mol} \mathrm{~L}^{-1}$ apparent $\mathrm{pH} 6.9)$ was held at $E_{\text {ap }}-1.0 \mathrm{~V} v s . \mathrm{Ag} / \mathrm{AgCl}$, with consumption of $7.8 \mathrm{~mol}^{\text {electron }} \mathrm{mol}^{-1}$ (10\% of the initial current remained).

\section{Results and Discussion}

The adsorption process of TRF on chitosan was studied through UV-Vis spectroscopy, by measuring the absorbance values of the solutions of TRF in the presence and absence of the biopolymer, after addition of electrolytes and by additional analysis of temperature effects, to get physicochemical parameters that would allow the investigation of the mechanism of interaction.

Figure 1 shows the graph relative to the amount of TRF adsorbed on chitosan as a function of time. It can be seen that the adsorption equilibrium is reached rapidly. From this experiment, $90 \mathrm{~min}$ of contact were considered enough for each experiment in order to obtain the adsorption isotherms.

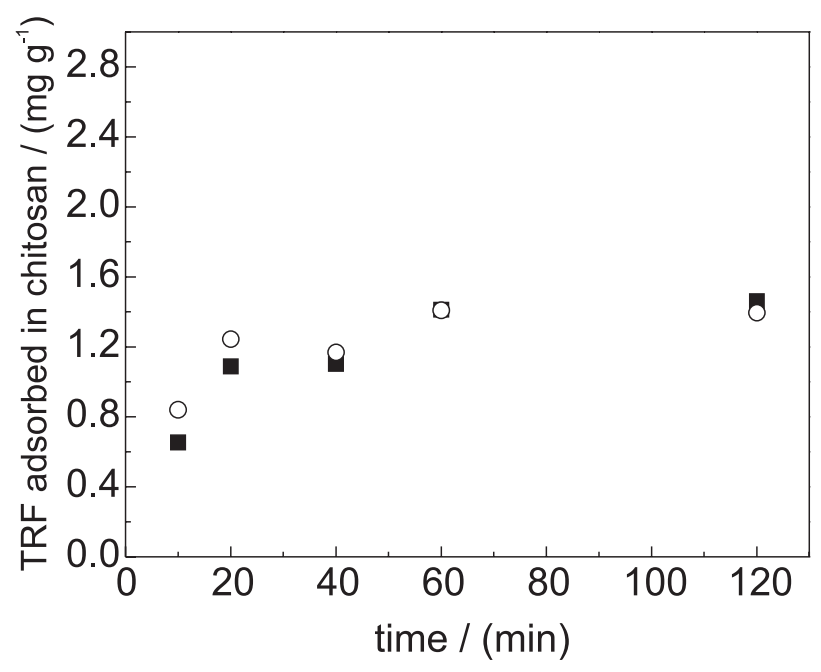

Figure 1. Adsorption of TRF on chitosan as a function of time at $298 \mathrm{~K}$. $0.180 \mathrm{~g}$ of chitosan and $0.010 \mathrm{~g} \mathrm{~L}^{-1}$ of TRF. Experiments were performed in duplicate.
Concerning temperature effects, results for the adsorption of TRF on chitosan at 298, 303, 308 and $313 \mathrm{~K}$ without ionic strength control are shown in Figure 2. These isotherms did not reach a well-defined plateau and the adsorption seems to be affected by temperature.

In the present study, the experimental data for the $\mathrm{TRF}+$ chitosan equilibrium isotherm were analyzed according to the Freundlich and Langmuir isotherm models. ${ }^{30}$ The Freundlich isotherm explains adsorption on a heterogeneous surface with uniform energy. The adsorption process under investigation does not obey the Freundlich isotherm model because no linear relationship (data not shown) was found for this adsorption process.

On the other hand, in the Langmuir model, ${ }^{30,31}$ it is assumed that the thickness of the adsorbed layer is monomolecular in nature. The linear form of the isotherm is shown in equation 1 :

$$
\frac{C e q}{\Gamma}=\frac{1}{\Gamma_{m} K}+\frac{C e q}{\Gamma_{m}}
$$

where $\mathrm{Ceq}$ is the equilibrium concentration in the supernatant $\left(\mathrm{mg} \mathrm{L}^{-1}\right), \Gamma$ is the amount of herbicide adsorbed on solid $\left(\mathrm{mg} \mathrm{g}^{-1}\right), \Gamma_{\mathrm{m}}$ is the maximum adsorption capacity $\left(\mathrm{mg} \mathrm{g}^{-1}\right)$, and $K$ is a constant related to the intensity of the adsorption $\left(\mathrm{L} \mathrm{mg}^{-1}\right)$. The forms of the isotherms of TRF at 298, 303, 308 and $313 \mathrm{~K}$ were found to be linear over the whole studied concentration range and the corresponding correlation coefficients were satisfactory $(r=0.995)$. These values suggest that TRF-chitosan adsorption data follow the Langmuir sorption model. All constant values obtained by this model and thermodynamic parameters $\left(\Delta G_{a d s}^{0}\right.$ and $\Delta H_{a d s}^{0}$ of the adsorption process are represented in Table 1. The standard free energy change $\left(\Delta G_{a d s}^{0}\right)$ and enthalpy change $\left(\Delta H_{a d s}^{0}\right)$ of the adsorption process are calculated by,

$\Delta G_{a d s}^{0}=-R T \ln K$

where $\mathrm{R}$ is the gas constant $\left(8.314 \mathrm{~J} \mathrm{~K}^{-1} \mathrm{~mol}^{-1}\right), T$ is the absolute temperature. From the $K$ values, the $\ln K \times 1 / T$ van't Hoff plot can provide the adsorption process enthalpy change using the following equation,

$$
\frac{\partial(\ln K)}{\partial(1 / T)}=-\frac{\Delta H_{a d s}^{0}}{R}
$$

The amount of trifluralin adsorbed on chitosan decreases when the temperature increases, indicating a TRF desorption process from chitosan. The obtained enthalpic value of $-10.2 \pm 0.8 \mathrm{~kJ} \mathrm{~mol}^{-1}$ confirms that the TRF-chitosan interaction is exothermic and thus less 
Table 1. Adsorption and thermochemical data on the TRF-chitosan interaction

\begin{tabular}{lccccc}
\hline Adsorbent & Temperature $/(\mathrm{K})$ & $\Gamma_{\mathrm{m}} /\left(\mathrm{mg} \mathrm{g}^{-1}\right)$ & $K /\left(\mathrm{L} \mathrm{g}^{-1}\right)$ & $\Delta G_{a d s}^{0} /\left(\mathrm{kJ} \mathrm{mol}^{-1}\right)$ & $\Delta H_{a d s}^{0} /\left(\mathrm{kJ} \mathrm{mol}^{-1}\right)$ \\
\hline Chitosan & 298 & 31.8 & 126.3 & -11.9 & -10.2 \\
& 303 & 30.7 & 117.3 & -12.0 & \\
& 308 & 29.2 & 94.7 & -11.7 & \\
\hline
\end{tabular}
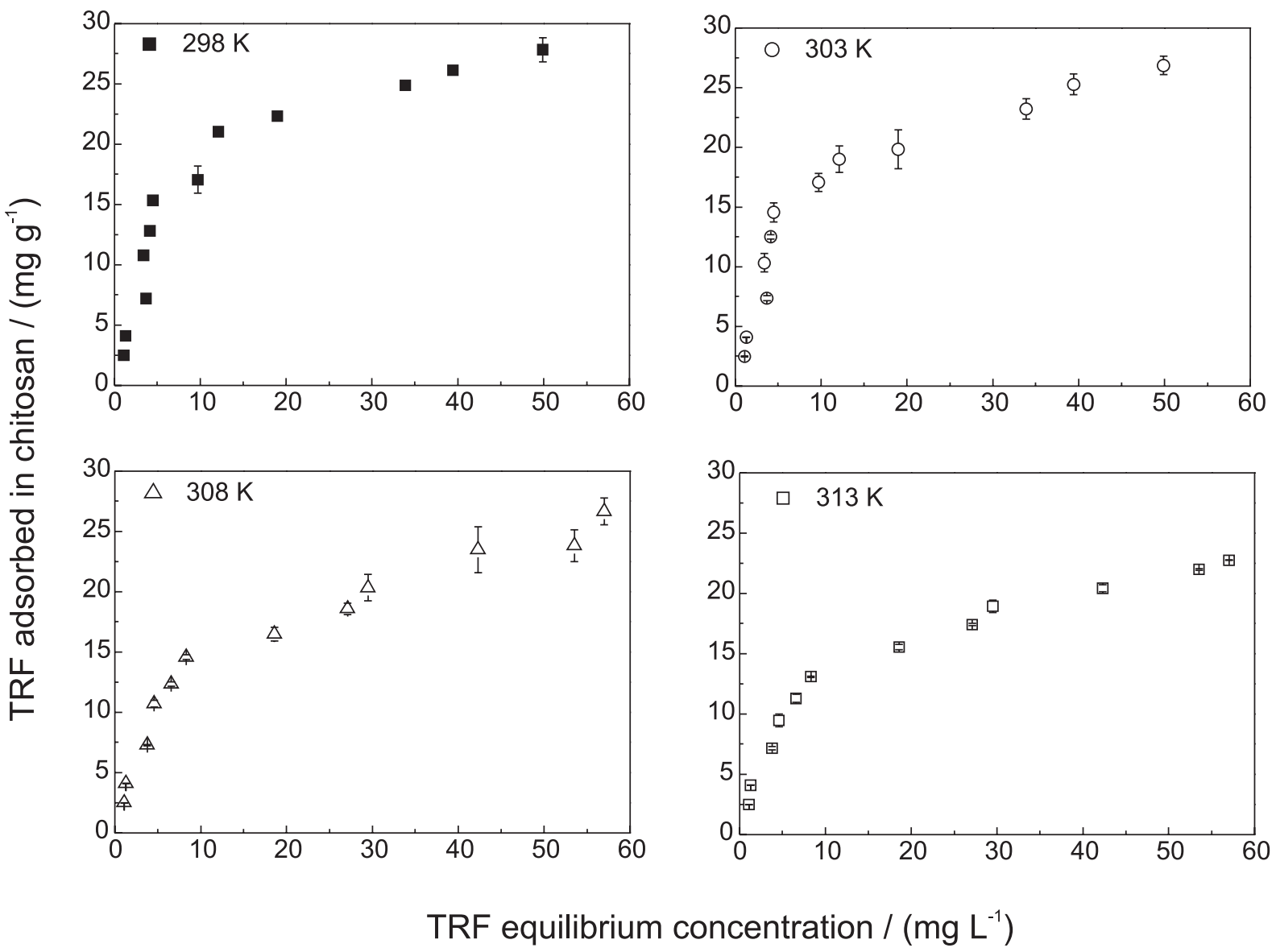

Figure 2. Adsorption isotherms of TRF on chitosan as a function equilibrium concentration at 298, 303, 308 and $313 \mathrm{~K}$ without added salt. Average of experiments in triplicate.

favorable at higher temperature. This enthalpic value suggests that the adsorption process involves electrostatic attractions, possibly, between the protonated amine group of chitosan $\left(\mathrm{R}^{-\mathrm{NH}_{3}^{+}}\right)$and the negative dipole of the nitro group of TRF, as represented in Figure 3. Another alternative, not shown, would be between the ammonium salt and the aromatic tertiary amine.

The standard free energy value obtained indicates that the adsorption process is spontaneous in nature and that TRF+chitosan interaction is a thermodynamically favorable process for the range of temperatures evaluated. ${ }^{32}$

Figure 4 shows the adsorption of TRF on chitosan with ionic strength control. In this isotherm, the adsorbed amount of TRF reached a plateau about $17 \mathrm{mg} \mathrm{g}^{-1}$.
The effect of ionic strength on the adsorbed amount is negligible when the TRF concentration is low, when compared with the isotherm in the absence of added salt (Figure 2, at $298 \mathrm{~K}$ ). However, when TRF concentration is increased, the amount of adsorbed species decreased. An increase in ionic strength of the bulk medium causes a decrease of the coulombic attraction between the dipole of the TRF molecule and the ammonium group of chitosan $\left(\mathrm{R}^{-} \mathrm{NH}_{3}^{+}\right.$), leading to a lower degree of adsorption.

There is a strong interest in the quantification of trifluralin in drinking water, in air and solids. Trifluralin may be extracted with dichloromethane and determined by capillary gas chromatography with a nitrogen-phosphorus detector. The method sensitivity is $0.05 \mu \mathrm{g} \mathrm{L}{ }^{-1}{ }^{24}$ Electrochemical 


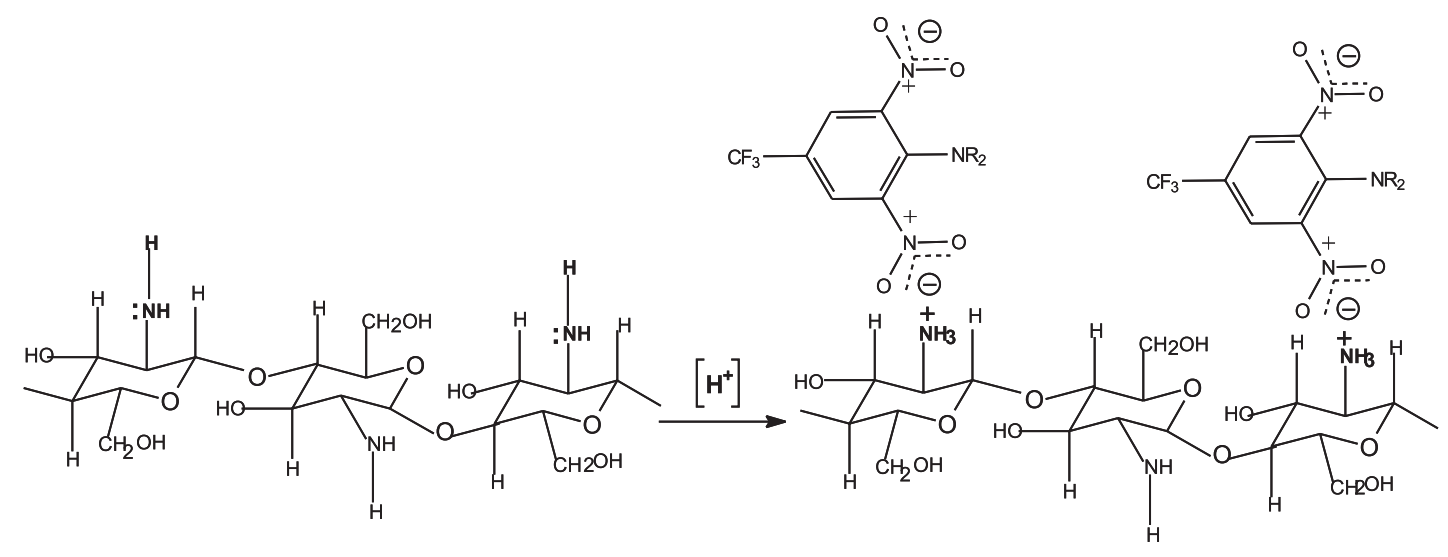

Chitosan

Protonated chitosan

Figure 3. Scheme related to the electrostatic attraction of $\mathrm{RNH}_{3}{ }^{+}$and nitro groups of TRF.

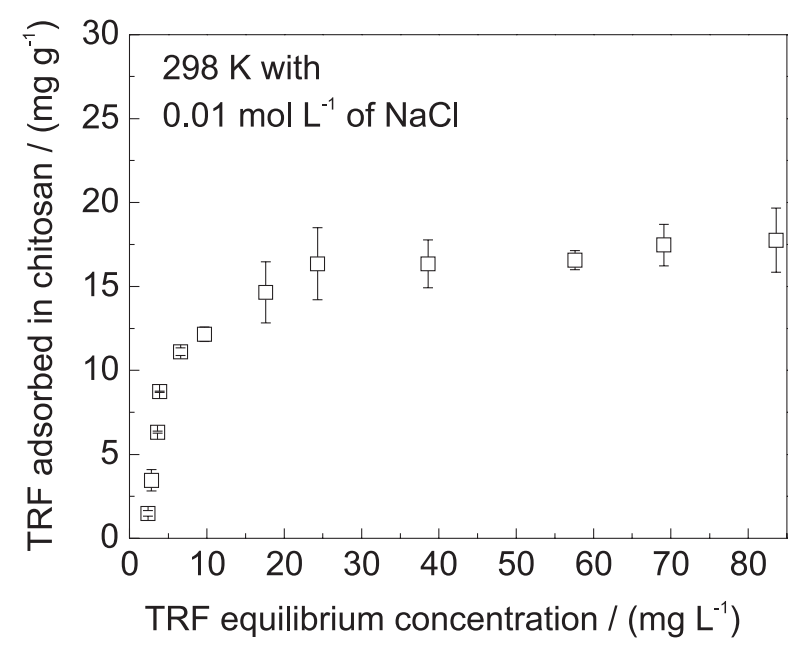

Figure 4. Adsorption isotherms of TRF on chitosan as a function of equilibrium concentrations at $298 \mathrm{~K}$ with $0.01 \mathrm{~mol} \mathrm{~L}^{-1}$ of $\mathrm{NaCl}$. Average of experiments in triplicate.

methods present the advantages of simplicity and high sensitivity. Indeed, differential pulse polarography at dropping mercury electrode was used to establish an electroanalytical procedure for the determination of TRF in formulations, soils and grains. Quantitative measurements were successful in the concentration range of $1.25 \times 10^{-5}$ to $2.85 \times 10^{-9} \mathrm{~mol} \mathrm{~L}^{-1}$, the lower concentration representing the detection limit by differential pulse polarography. ${ }^{28}$ However, despite very good detection limits obtained there are some environmental problems related to the use of mercury and also related to the direct electrochemical detection of related nitrocompounds, due to adsorption on the most conventional electrodes. In this context, chemically modified electrodes (CMEs) have been widely used as sensitive and selective analytical methods for detection and quantification of several classes of compounds. In this context, the surface modification of conventional electrodes is an important development in electroanalysis. ${ }^{20}$
Based on the above reported results on adsorption, the use of a chitosan-modified electrode looks like a logical choice for improvement of electroanalytical procedures. For comparison purposes, a bare GCE was used, to obtain the reduction mechanism of TRF.

\section{Electrochemical results}

The reduction of TRF on a GCE in aqueous phosphate buffer + ethanol (1:1) $0.2 \mathrm{~mol} \mathrm{~L}^{-1}$; (apparent pH 6.9) was examined by $\mathrm{CV}$, which showed two irreversible reduction waves with $E_{\mathrm{pIc}}$ of $-0.795 \mathrm{~V}$ and $E_{\mathrm{pIIc}}$ of $-0.968 \mathrm{~V}$ at $0.100 \mathrm{~V} \mathrm{~s}^{-1}$ and corresponding anodic waves at $E_{\text {pla }}$ of $0.264 \mathrm{~V}$ (Figure 5), similarly to already reported results using mercury electrode ${ }^{28}$ This individual reduction peaks are due to the well-known $4 \mathrm{e}^{-} / 4 \mathrm{H}^{+}$reduction of the nitro groups to produce the corresponding hydroxylamine derivative. The reduction of the two nitro groups to hydroxylamine functions was confirmed by coulometry with consumption of $7.75 \mathrm{~mol}$ electron $\mathrm{mol}^{-1}$. The $\mathrm{pH}$ effect on the reduction waves followed already reported data, with measurement of pKa of $c a$. 5.3, related to dissociation of the ammonium group of TRF. ${ }^{28} \mathrm{It}$ should be emphasized that at $\mathrm{pH} 6.9$, chosen for additional experiments, TRF appears in its neutral form.

DPV of TRF was also performed in the same conditions and revealed the presence of two peaks at $-0.687 \mathrm{~V}$ and $0.795 \mathrm{~V}$ (Figure 6).

Through the studies presented earlier in this paper, it was proven that TRF adsorbs on chitosan, fact that directed our choice for the preparation of a chitosan modified glassy carbon (GC/CHI) electrode (see experimental). $\mathrm{CV}$ of the supporting electrolyte (phosphate buffer + ethanol (1:1) $0.2 \mathrm{~mol} \mathrm{~L}^{-1}$; apparent $\mathrm{pH} 6.9$ ) shows that the background current of $\mathrm{GC} / \mathrm{CHI}$ electrode was very low and no peak appeared in the entire potential window. The $\mathrm{pH}$ analysis 


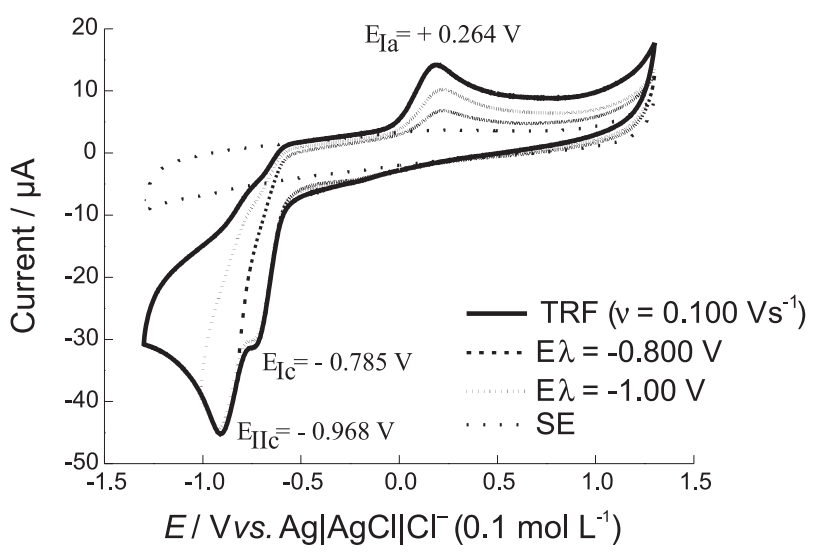

Figure 5: Cyclic voltammograms (CV) of TRF on GCE in phosphate buffer + ethanol (1:1), $0.2 \mathrm{~mol} \mathrm{~L}^{-1}, c_{\mathrm{TRF}} 1.0 \times 10^{-3} \mathrm{~mol} \mathrm{~L}^{-1}, \mathrm{v}=0.100 \mathrm{~V} \mathrm{~s}^{-1}$, with different inversion potentials.

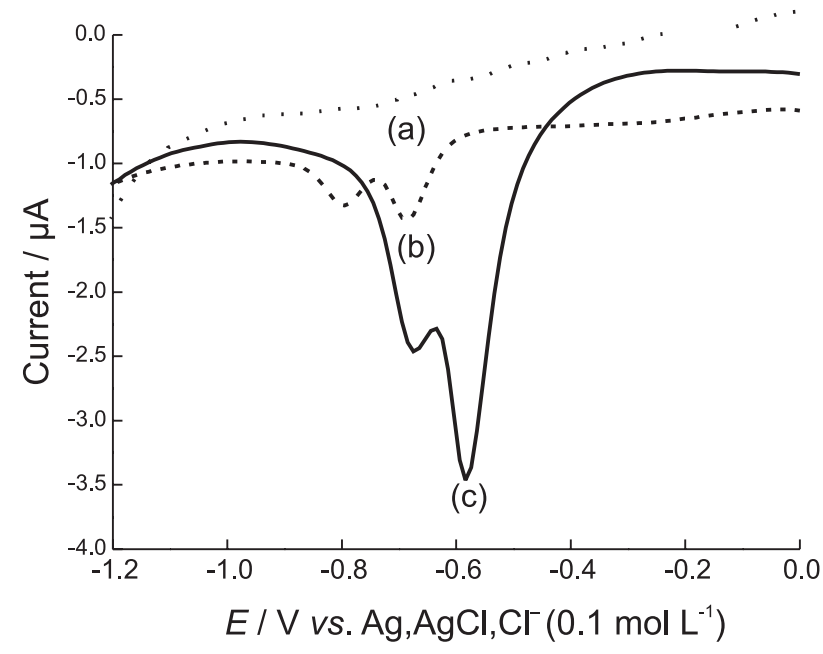

Figure 6. Differential pulse voltammograms obtained in $0.2 \mathrm{~mol} \mathrm{~L}^{-1}$ phosphate buffer + ethanol (7:3), $\mathrm{pH}_{\text {ap }}=6.9$ for TRF, (a) on modified $\mathrm{GC} / \mathrm{CHI}$ electrode in supporting electrolyte, in the absence of the analyte, (b) on GCE in TRF solution $\left(c_{\mathrm{TRF}} 5.79 \times 10^{-6} \mathrm{~mol} \mathrm{~L}^{-1}\right)$ and (c) on modified $\mathrm{GC} / \mathrm{CHI}$ electrode in TRF solution $\left(c_{\mathrm{TRF}} 5.79 \times 10^{-6} \mathrm{~mol} \mathrm{~L}^{-1}\right)$. Concentration of chitosan on the GCE $=30 \mathrm{mg} \mathrm{L}^{-1}$. DPV parameters: pulse amplitude $50 \mathrm{~ms}$; pulse width $70 \mathrm{~ms}$; scan rate $20 \mathrm{mV} \mathrm{s}^{-1}$.

was not performed, once it is well-known that chitosan dissolves in acidic medium and repulsion could have occurred between chitosan and TRF $(\mathrm{pKa}=5.3)$, both present as ammonium salts. Basic medium was also precluded, once chitosan would be deprotonated, losing its ability to attract TRF.

In the presence of TRF, when compared to the bare GCE, the currents of both reduction peaks were greatly increased (Figure 6) in $\mathrm{GC} / \mathrm{CHI}$ electrode and anodic potential shifts were also observed $\left(\Delta E_{\mathrm{pIc}}=106 \mathrm{mV}\right)$. Through cycling in the cathodic region, it was observed that the peak current intensities do not decrease, showing the stability of the modified electrode. The reason is that the chitosan, at acidic $\mathrm{pH}$ values, is a highly positive charged species, and, as proved before, it attracts TRF and allows its adsorption through the dipolar nitro group present into the electrode surface (Figures 3 and 6).

The effects of the concentration of chitosan on the electrode and of the incubation time of the modified electrode in the solution were studied. The concentration of the polyelectrolyte increases the electrode response of TRF up to $20 \mu \mathrm{L}$ of a solution of chitosan $\left(30 \mathrm{mg} \mathrm{L}^{-1}\right)$ addition and the response signal got constant when the incubation time reached $10 \mathrm{~min}$ (data not showed).

The repeatability of response current of the GC/CHI electrode was investigated at a TRF concentration of $5.79 \times 10^{-6} \mathrm{~mol} \mathrm{~L}^{-1}$. The variation coefficient was $2 \%$ for three successive assays. The modified electrodes of different batches showed reproducibility with a variation coefficient of $4.2 \%$ for the current determination of TRF concentration, at the same concentration.

Figure 7 shows the calibration curve obtained using TRF on the GC/CHI electrode. The peak height increases linearly with the concentration of TRF in the range of $2.49 \times 10^{-7}-5.79 \times 10^{-6} \mathrm{~mol} \mathrm{~L}^{-1}$ with $\mathrm{r}$ of 0.995 . The obtained linear equation was $I_{\mathrm{pc}}(\mathrm{TRF})=-0.05977+0.28558$ $([\mathrm{C}] / \mathrm{M})(n=9)$.

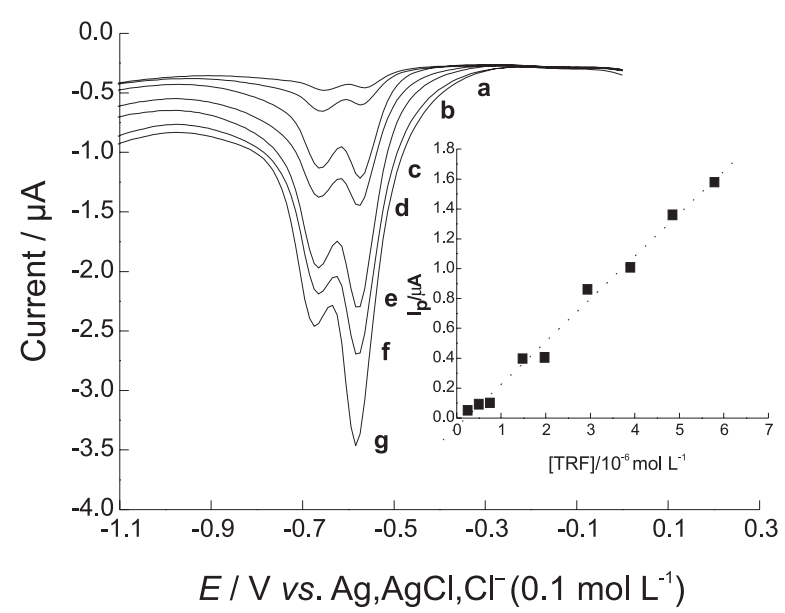

Figure 7. Differential pulse voltammograms of phosphate buffer + ethanol (7:3) $\left(\mathrm{pH}_{\mathrm{ap}}, 6.9\right)$ in the presence of $c_{\mathrm{TRF}}$ of: (a) 2.49 , (b) 7.45 , (c) 1.48 , (d) 1.97 , (e) 2.94 , (f) 3.90 , and (g) $5.79 \mu \mathrm{mol} \mathrm{L}^{-1}$. (Inset) Plot of $I_{\mathrm{pc}}$ as a function of TRF concentration. DPV parameters: pulse amplitude $50 \mathrm{~ms}$; pulse width $70 \mathrm{~ms}$; scan rate $20 \mathrm{mV} \mathrm{s}^{-1}$.

A detection limit of $7.45 \times 10^{-8} \mathrm{~mol} \mathrm{~L}^{-1} \mathrm{TRF}$ was estimated (determined as corresponding to three times of S. D. of the zero-dose response), that allows to quantify within the acceptable limits allowed, for example, in drinking water. This value is much smaller than that observed on the bare glassy carbon electrode $\left(4.58 \times 10^{-6} \mathrm{~mol} \mathrm{~L}^{-1}\right)$, although higher than the ones obtained using DPP and mercury, ${ }^{28,29}$ however the present method is environmentally friend and very easy and cheap to achieve. 


\section{Conclusions}

The adsorption of TRF on chitosan was spectrophotometrically investigated and results showed eletrostatic interaction between the ammonium group of chitosan and the negative dipole of the substituent groups on the TRF molecule. The adsorption process showed to be dependent on ionic strength. TRF showed two irreversible peaks relative to the reduction of the nitro groups. The electroanalytical method for the quantification of TRF had been investigated on GCE and GC/CHI electrodes in phosphate buffer + ethanol (7:3) solution (ionic strength $\left.0.2 \mathrm{~mol} \mathrm{~L}^{-1}\right)$. The results indicated that the currents of TRF reduction peaks were greatly enhanced on the modified electrode due to the adsorption/accumulation of TRF onto the electrode surface, as observed by adsorption studies. According to the experimental data, a simple and sensitive electrochemical procedure for determination of TRF was developed.

\section{Acknowledgments}

The financial support by the Brazilian agencies CNPq, CAPES, PADCT/CNPq, FAPEAL, BNB (Banco do Nordeste do Brasil), CNPq/CTHIDRO (process 151874/2007-7) and RENORBIO is greatly acknowledged.

\section{References}

1. WHO, Trifluralin in Drinking-Water. Background Document for Preparation of WHO Guidelines for Drinking Water Quality; Geneva, World Health Organization (WHO/SDE/WSH/03.04/43), 2003, pp. 1-4.

2. Sanders P. F.; Seiber J. N.; Chemosphere 1983, 12, 999.

3. Wauchope, R. D.; Buttler, T. M.; Hornsby, A. G.; AugustijnBeckers, P. M.; Burt, J. P.; Rev. Environ. Contam. 1992, T123, 1.

4. Sanusi, A.; Millet, M.; Mirabel, P.; Wortham, H.; Sci. Total Environ. 2000, 263, 263.

5. Wheeler, W. B.; Stratton, G. D.; Twilley, R. R.; Ou, L. T.; Carlson, D. A.; Davidson, J. M.; J. Agric. Food Chem. 1979, 27, 702 .

6. Golab T.; Occolowitz J. L.; Biomed. Mass Spectrom. 1979, 6, 1.

7. Parr J. F.; Smith, S.; Soil Science 1973, 115, 55.

8. Kumar, M. N. V. R.; Reac. Funct. Polym. 2000, 46, 1.

9. Babel, S.; Kurniawan, T. A.; J. Hazard. Materials 2003, 97, 219.

10. Blackburn, R. S.; Environ. Sci. Technol. 2004, 38, 4905.

11. Chang, M.; Juang, R.; Colloids Surf. A: Physicochem. Eng. Aspects 2005, 269, 35.
12. Chang, M.; Juang, R.; J. Colloid Interface Sci. 2004, $278,18$.

13. Monteiro, O. A. C.; Airoldi, C.; J. Colloid Interface Sci. 1999, $212,212$.

14. Chatterjee, S.; Chatterjee, B. P.; Das, A. R.; Guha, A. K.; J. Colloid Interface Sc. 2005, 288, 30.

15. Crini, G.; Bioresource Technol. 2006, 97, 1061.

16. Paulino, A. T.; Minasse, F. A. S.; Guilherme, M. R.; Reis, A. V.; Muniz, E. C.; Nozaki, J.; J. Colloid Interface Sci. 2006, 301, 479.

17. Prado, A. G. S.; Macedo, J. L.; Dias, S. C. L.; Dias, J. A.; Colloids Surfaces B: Biointerfaces 2004, 35, 23.

18. Takahashi, T.; Imai, M.; Suzuki, I.; Biochem. Engineering J. 2005, 25, 7 .

19. CONAMA - Conselho Nacional do Meio Ambiente - Revisão da resolução 020/86 "Classificação e enquadramento de corpos de água", 12 e 13 de junho de 2003. (www.mma.gov.br).

20. Galli, A.; De Souza, D.; Garbellini, G. S. ; Coutinho, C. F. B. ; Mazo, L. H.; Avaca, L. A.; Machado, S. A. S.; Quim. Nova 2006, 29, 105.

21. Chen, Y-I.; Su, Y. S.; Jen, J. F.; J. Chromatogr. A 2002, 976, 349.

22. Huang, G.; Ouyang, J.; Baeyens, W. R. G.; Yang, Y.; Tao, C. ; Anal. Chim. Acta 2002, 474, 1.

23. Chagas, C. M.; Queiroz, M. E. L. R.; Neves, A. A.; Quim. Nova 1999, 22, 506.

24. Hyang-Rang, J. ; Mostafa, A.; Soon-Kil, C.; Jeong-Heui, C.; Kil-Yong, K.; Ro-Dong, P.; Jae-Han, S.; J. Sep. Sc. 2007, 30, 1953.

25. Hegedüs, G.; Bélai, I.; Székács, A.; Anal. Chim. Acta 2000 , $421,121$.

26. Del Carlo, M.; Mascini, M.; Pepe, A.; Diletti, G.; Compagnone, D.; Food Chem. 2004, 84, 651.

27. Poganik, L.; Franke, M.; Biosens. Bioelectron. 2003, 18, 1.

28. Sreedhar N. Y.; Samatha K. R.; Reddy P. R. K.; Reddy S. J.; Int. J. Environ. Anal. Chem. 1998, 72, 247.

29. Arranz, A.; Fdez de Betoño, S.; Moreda, J. M.; Arranz, J. F.; Talanta 1997, 45, 417.

30. Lyklema, J.; Fundamentals of Interface and Colloid Science, Academic Press: London, 1991, vol. 1, ch. 1, p. 1.

31. Myers, D.; Surfaces, Interface and Colloids: Principles and Applications, $2^{\text {nd }}$ ed., John Wiley \& Sons: New York, 1999, ch. 9, p. 180.

32. Dos Anjos, F. S. C.; Vieira, E. F. S.; Cestari, A. R.; J. Colloid Interface Sci. 2002, 253, 243.

Received: October 1, 2007 Web Release Date: April 11, 2008 